\title{
A felsőoktatás nemzetköziesedésének történelmi vetületei, mint az innováció és a tudásáramlás történelmi példái
}

\section{Historical Aspects of the Internationalisation of the Higher Education as Historical Examples of Innovation and Knowledge Transfer}

\section{P. M. KőMÍVES}

Debreceni Egyetem, Gazdaságtudományi Kar, Vezetés- és Szervezéstudományi Intézet; Debreceni Egyetem Ihrig Károly Gazdálkodás- és Szervezéstudományok Doktori Iskola komives.peter.miklos@econ.unideb.hu

Absztrakt. A felsőoktatás nemzetköziesedése az oktatásszervezés egyik kiemelkedő aktualitással bíró részterülete, amely megoldást jelenthet a magyar felsőoktatásban a demográfiai okokból várhatóan bekövetkező hallgatói létszámcsökkenésre. A felsőoktatás nemzetköziesedése azonban annak ellenére sem újkeletü jelenség, hogy annak népszerüsége az elmúlt évtizedek során jelentősen emelkedett, mára igen elterjedtté vált. A cikk célja, hogy bemutassa a felsőoktatás nemzetköziesedésének történelmi vetületeit, példáit szakirodalmi források és kutatás alapján.

Abstract. The internationalisation of the higher education is one of the most actual topics of the education management nowadays. It can bring a solution for the problems of the Hungarian higher educational institutions caused by the demographically expected decrease of the number of students. The internationalisation of the higher education is not a new-fangled phenomenon however it became much popular in the last decades and it has been spread globally. The aim of this article to show the historical aspects of the internationalisation in higher education based on literature review and research.

\section{Bevezetés}

A felsőoktatási rendszer működésének egyik legfontosabb eleme napjainkban a felsőoktatás nemzetköziesedése, amely a társadalmak és a gazdaságok globalizálódásának hatására évtizedek óta a közérdeklődés és a kutatások középpontjában áll [1]. A felsőoktatás nemzetköziesedése azonban korántsem újkeletű folyamat, hiszen a középkortól fogva egészen a 18-19. századig a maihoz hasonló felsőoktatási rendszer múködött a világ számos országában, mobilis oktatókkal és hallgatókkal, illetve közös nyelvvel, amely ekkoriban még a latin volt. A 18-19. században megváltozott az egyetemek szerepe, az oktatás nemzeti nyelven zajlott, a nemzeti célok egyértelmű prioritásként jelentek meg, a 
mobilitás pedig egyes esetekben egyenesen tiltott lett. Az első világháborút követően sikertelenül próbálták a felsőoktatást a nemzetközi béke hídépítőjeként használni - sikertelenül. A hidegháború időszakában a vasfüggöny két oldalán párhuzamos nemzetköziesedési struktúrák alakultak ki, amelyek a keleti blokk bukását követően tudtak a nyugati rendszerbe integrálódni [2].

A felsőoktatás nemzetköziesedését két irányból lehet vizsgálni: egyfelől az oktatók és hallgatók külföldi mobilitása, másfelől pedig a külföldi oktatók és hallgatók egy adott intézményben, felsőoktatási rendszerben való jelenléte szempontjából. Emellett megkülönböztetünk rövid és hosszú távú mobilitási programokat is, amelyek időtartama és célja egymástól lényegesen eltér, hiszen a rövidebb idejű mobilitás - hallgatók esetében legalábbis - jellemzően kreditmobilitást, míg a hosszabb távú mobilitás akár diploma külföldi megszerzését is jelentheti.

A cikk célja, hogy a felsőoktatás nemzetköziesedésének, illetve bizonyos esetekben nemzetköziesítésének történetét vizsgálja úgy az egyetemes, mint a magyar oktatásszervezés forrásai alapján. A nemzetköziesedés történetének vizsgálata kulcsfontosságú a mai nemzetköziesedési tendenciák megértése szempontjából. A történelmi példák vizsgálata megkönnyíti az aktuális folyamatok, nemzetközi tendenciák megértését.

\section{Alkalmazott módszerek}

Jelen kutatás célja a magyar és egyetemes oktatásfejlődés szempontjából jelentős hatást gyakorló felsőoktatási nemzetköziesedés történelmi fejlődésének feltárása volt szekunder források alapján. A társadalmi kutatás Babbie szerinti három legfontosabb célja a felfedezés, a leírás és a magyarázat [3], amelyek közül jelen cikk elsősorban a leírás és a magyarázat céljait kívánja beteljesíteni a tudományra az utóbbi évtizedekben egyre jellemzőbb multidiszciplináris szemléletmód alkalmazásával [4]. A cikk szekunder adatforrások feldolgozására épül, amely keretében az oktatásmenedzsment, a gazdálkodásés szervezéstudományok és az oktatástörténet jelentős magyarországi és külföldi szakirodalmakat dolgoz fel.

A szekunder források alapján elvégzett kutatások előnye a költséghatékonyság mellett a viszonylag gyors munka lehetősége. Mindez azért lehetséges, mert a szekunder forrásfeldolgozás már létező adatok elemzésén alapul, azok feldolgozásából ér el új vagy újszerú tudományos eredményeket. A szekunder forrásfeldolgozás veszélyét az jelenti, hogy a kutató kiszolgáltatott az eredeti adatfelvétel hitelességének, vagyis a kutatás végzése során kiemelt figyelmet kell fordítani a feldolgozott adatok minőségének, megbízhatóságának [5]. Minderre tekintettel jelen cikk készítése során kiemelt figyelmet fordítottam a források hitelességének. A feldolgozott források jellemzően a szakterület vezető hazai és nemzetközi periodikáiban, vagy a legnevesebb könyvkiadók gondozásában jelent meg. A feldolgozott forrásokat megjelentető fórumok gondos szerkesztési és lektorálási folyamata garantálja a feldolgozott források hitelességét.

\section{A felsőoktatás nemzetköziesedésének egyetemes fejlődése}

A felsőoktatási mobilitás egyike az oktatási rendszert érintő legjelentősebb aktualitásoknak, ugyanakkor tudható, hogy ez a jelenség már évszázadok óta meghatározza a tudomány, a kutatás és a 
felsőfokú képzések világát is. Mint arra Vámos is rámutat, szinte kivétel nélkül minden olyan kutató, aki életpályája során jelentős tudományos sikert ért el, valamilyen módon eljutott tanulmányai, tudományos múködése során azokba a nagy szellemi központokba, amelyek alapjaikban voltak képesek meghatározni koruk tudományos életét, kutatási irányzatait. Ezek a kutatói közösségek jelentős pozitív hatást képesek gyakorolni az itt dolgozó kutatókra és vendégkutatókra, ösztöndíjasokra is [6]. Európa történelmét jelentősen befolyásolták az itt működő szellemi műhelyek, hiszen az itt tanult művészek, tudósok és politikusok töltötték be azokat a fontos pozíciókat, amelyek az egész kontinens - és az egész világ - fejlődésére kihatással tudtak lenni. A középkori, később pedig a modern és a posztmodern Európa is a tudás hatalmára épült. Az intézmények az universitas fogalmától az univerzalitás eszményéig jutottak el [7].

Gonon szerint a Diderot és d'Alembert-féle Enciklopédia az utazás (Voyage) szó magyarázatánál külön figyelmet szentel a tanulmányi célú utazásoknak. Megfogalmazásuk szerint a jó államnak könnyebbé kell majd tennie az utazást annak érdekében, hogy a fiatalok könnyebben utazhassanak, és hogy az idősebbeket is gazdagabbá tehessék (elsősorban szellemi értelemben). Az Enciklopédia meghatározza az utazástól elvárt eredményeket, amelyek közül kiemelkedik az idegen országok kultúrájának megismerése, illetve a gazdasági és kereskedelmi kapcsolatok kiépítése. Diderot és d'Alembert szerint - Gonon hivatkozása alapján - a tanulmányi célú utakat nagyon precíz tervezésnek kell megelőznie, az ilyen utakra rá kell szánni a szükséges időt és lehetőség szerint egy meghatározott földrajzi célt kell felkeresni: Itáliát. Gonon Diderot és d'Alembert meghatározása mellett a Grand Tour, vagyis az úriemberhez méltó angol oktatási mobilitás jelentőségét is kiemeli, hiszen ez a külföldi tanulmányi forma nemcsak a nemesi, hanem a gazdag polgári származású angolok oktatásában is jelentős szerepet játszott [8].

A felsőoktatási mobilitás és a felsőoktatás nemzetköziesedésének gyökereit a középkorig visszavezető de Ridder-Symoens a mobilitásban elsőként részt vevő professzorokat és hallgatókat a zarándokokhoz hasonlította, csakhogy míg a vallásos zarándokok Jézus Krisztus vagy egy-egy szent sírjához igyekeztek eljutni, addig az első utazó diákok célja az volt, hogy egy-egy külföldi egyetemi városba érve tanulhassanak, új barátokra tehessenek szert és kellemesen tölthessék el idejüket [9].

Általánosan - és történelmi léptékben is - elfogadott nézet, hogy a felsőoktatásban nemzetközi mobilitásra nemcsak ott van szükség, ahol nincsenek vagy későn alakultak egyetemek, hanem minden időszakban és minden földrajzi területen nélkülözhetetlen ez a jelenség, hiszen annak és az az által generált tudásáramlás híján sem az értelmiségiek, se a tudósok képzése nem lehet kellőképpen megalapozott. Az új vagy újszerű tudományos eredmények elérése a tudományos élet nemzetközi tendenciáinak ismerete és a nemzetközi tapasztalatok felhalmozása nélkül nem volna lehetséges. A külföldi egyetemek felkeresése éppen ezért a magyar oktatástörténet során is mindvégig kiemelt jelentőséggel bírt [10].

Réau szerint a középkortól fogva a felsőoktatási mobilitás (a korabeli szóhasználattal: peregrinatio academica) jelentősége egyre nőtt. Az 1400-as években csak a hallgatók körülbelül 10\%-a mondhatta el magáról, hogy több mint egy felsőoktatási intézményben folytatott tanulmányokat, vagyis a peregrinációt egy erősen limitált jelenségként lehet leírni. Ehhez képest az újkori, azaz 16-17. századi egyetemek hallgatói között már nagyobb számban jelentek meg külföldiek Európa minden tájáról. 
Ugyanakkor azt is okvetlen kiemelendő, hogy a hallgatói mobilitás a tudás áramlása mellett a társadalmi tőke mobilitását is jelentette elsősorban az olyan tekintélyes egyetemvárosok esetében, mint amilyen például Párizs volt. A jogot vagy orvostudományokat tanuló hallgatók körében elterjedtebb volt a nemzetközi mobilitás, mint a teológusok vagy a bölcsészetekkel-művészetekkel foglalkozó társaik körében [11]. A teológusok mobilitásáról alkotott képet ugyanakkor tovább árnyalhatja, hogy a XII. században megalapított párizsi egyetem több évtizeden át pápai monopóliummal bírt a hittudományi kar alapítását illetően. Ebben az időszakban tehát mindazok, akik teológiai fakultáson szerettek volna tanulni, kénytelenek voltak Párizsba utazni. Így tettek a korban ismert magyar hallgatók is, akik között több későbbi professzor is akadt [12].

Noha Altbach az egyetemeket az egyetlen olyan intézményként definiálja, amely mindig globalizált formában működött [13], ezt a meglátást célszerű némi kritikával illetni, hiszen - mint arra de Wit és Merkx is rámutat - a 18-19. században az egyetemek a nemzeti identitás fontos elemeivé váltak, amely értéket alapvetően az európaizáció ellenében határozták meg [14]. Erre az időszakra tehető, hogy a latin nyelvet az egyes felsőoktatási rendszerek hivatalos nyelveként a nemzeti nyelvek váltották [15]. Ebben az időszakban alakultak ki jelentősebb különbségek az egyes egyetemeken oktatott képzések kurrikulumai, a képzéssel megszerezhető végzettségek és az egyes képzések minősége között is. A nemzetállamok hatása a felsőoktatásra - vagyis a nemzetállamok és az egyetemek közötti kapcsolat jelentősen felerősödött [16]. Természetesen nemcsak magyarok tanultak külföldön. Skóciából például számos peregrináló diák ismert: Orléans, Párizs, Wittenberg és más német egyetemek vagy Itália sem maradhatott ki az úti célok közül, de a 17. században Angers-ben a jogtudományok professzorává nevezték ki William Barclay-t, tehát a skót jogászok esetében kimondottan sikeresnek minősíthető a tanulmányi célú mobilitás [17]. Keleti példákat vizsgálva megállapíthatjuk, hogy Zsukovszkaja kutatásai során például több mint tíz olyan, I. Sándor cár uralkodása alatt külföldön tanuló hallgató életpályáját elemzi, akik később fontos szerepet játszottak a cári Oroszország tudományos fejlődésében. A vizsgált peregrináló hallgatók Helmstedt, Göttingen, Jéna, Berlin, Regensburg, Párizs vagy London egyetemein tanultak - egyebek mellett - botanikát, gyakorlati csillagászatot, ásványtant, zoológiát, diplomáciát, matematikát, földrajzot, gazdaságtant, statisztikát vagy éppen filozófiát [18]. Skandináv történészek is egyetértenek abban, hogy Észak-Európa öt országának (Dánia, Svédország, Finnország, Norvégia és Izland) fejlődésére is komoly hatást gyakoroltak a peregrináló diákok, akik Európa más részein folytatták tanulmányaikat természettudományos, jogi, teológiai, közigazgatási vagy más tudományterületeken [19].

\section{A felsőoktatás nemzetköziesedésének megjelenési formái a történelem során Magyarországon}

A Magyarországról kiinduló tanulási célú mobilitás első példái már a középkorból, az Árpádház uralkodása idejéről ismertek. Ekkoriban - magyar felsőoktatási intézmény híján - évszázadokon keresztül külföldi tanulmányok során sajátíthatták el a legmagasabb szintű tudást az arra hivatott magyarok. A mobilitás irányát részint meghatározták az uralkodói házasságok - III. Béla király második, francia felesége, Capet Margit királyné idején jelentősen megnőtt a párizsi egyetemen tanuló hallgatók száma, akik a friss tudást és kultúrát is magukkal hozták, amikor tanulmányaik végeztével visszatértek 
a királyi udvarba. Jogi tanulmányokat leggyakrabban Bolognában folytattak magyar diákok, akik - nagy létszámukra tekintettel - 1265-től önálló natiót, testületet alkottak az itáliai egyemen. A tanulmányi célú nemzetközi mobilitás egyre népszerübbé és gyakoribbá vált, hiszen például Padova város egyetemén Mátyás király uralkodásának kezdetéig összesen 97 fő, uralkodásának idején további 66 fő, míg 1526-ig újabb 160 magyarországi hallgató folytatott tanulmányokat. 1401-től egyre több magyar diák, azaz hungarus tanult Krakkóban, 1469-től pedig Prágában. Valószínűleg a földrajzi közelséggel is magyarázható, hogy Bécs egyetemén 1450-ig közel 3000 magyar hallgató fordult meg [12].

A reformáció idején évszázadokon keresztül felekezeti alapon szerveződött a hazánkból kiinduló tanulmányi célú mobilitás, és noha a célintézmények gyakorta nem vezettek nyilvántartást a hozzájuk beiratkozó hallgatók vallási meggyőződéséről, egyes intézményeket mégis szinte kizárólag protestáns, míg másokat szinte kizárólag római katolikus magyar diákok választottak külföldi tanulmányaik helyszínéül. A peregrinatio academica jelensége során külföldi tanulmányokat folytató hallgatók körében 1526 és 1800 között mindvégig túlsúlyban voltak a protestánsok. 1526 és 1600 között összesen 3492 külföldön tanuló magyar diákról van tudomása a hazai kutatóknak, akik közül 1899-en valamely protestáns vagy ortodox felekezethez tartoztak. 1601 és 1700 között összesen 10158 diákot ismerünk, akik közül 6244-en voltak protestánsok vagy ortodoxok, míg 1701 és 1800 között összesen 12705 akadémista közül 6938 volt protestáns vagy ortodox és további 52 zsidó diák is ismert ebből a korszakból [20].

Magyarországon a különböző felekezetek igyekeztek saját értelmiségi utánpótlásukat biztosítani külföldön képzett tehetséges akadémisták útján. Az unitáriusok körében is ismert és alkalmazott gyakorlat volt a peregrinatio academica, amelynek keretében az 1560-as évektől 1848-ig 178 unitárius akadémista folytatott külföldi tanulmányokat, összesen 281 különböző akadémiára beiratkozva az évszázadok során. A számadatokból jól látható, hogy tömegjelenségről nem volt ugyan szó, azonban a külföldön tanuló diákok hazatérve általában magas presztízsű hivatalokat foglalhattak el, amelynek jelentőségét az is növelte, hogy az unitáriusok Magyarország területén nem működtettek felsőoktatási intézményt. A legnépszerübb tanulmányi célpontok között megtalálhatóak Bécs, Pádua, Oderafrankfurt, Leiden, Wittenberg, Altdorf, Heidelberg és Göttingen is [21].

A tanulmányi célú mobilitás jelentősége a 18. században jóval nagyobb volt, mint napjainkban. Hegyi közlése szerint ugyanis például az orvostanhallgatók képzésében, amely tudományterület ma például a hazánk irányában működő tanulmányi célú mobilitás egyik legfontosabb közege, a tudományos eredmények kommunikációja és a tudás áramlása teljesen másképp zajlott, mint napjainkban. Míg manapság a legfontosabb tudományos forrásokat az orvostudományi szakfolyóiratokban publikált cikkek és közlemények jelentik, addig a 18. században a legfontosabb tudományos forrásnak a könyvek (monográfiák) számítottak. Hasonló tudományos jelentőséggel bírtak az egyetemi disszertációk, a tézisek és a tudományos vitákat, eszmecseréket rögzítő disputák is, csakhogy ezeket a kiadványokat még a nyugat-európai könyvkereskedőknél sem feltétlenül lehetett beszerezni, Magyarországon pedig, ahol II. József uralkodásáig intézményesült könyvkereskedői hálózat sem létezett, szinte lehetetlen volt ezekhez a kiadványokhoz hozzájutni. Vagyis a nyugat-európai egyetemen tett felfedezésekről, az ott folyó tudományos és szakmai vitákról abban az esetben tudott a hazai kutatói közvélemény értesülni (és ennek köszönhetően akkor tudtak az új tudományos eredmények a kurrikulumokba és az 
alkalmazott eljárásrendbe beépülni), ha a hazai felsőoktatási intézmények ki tudtak építeni valamilyen kapcsolati hálót a nyugati egyetemekkel. A kapcsolati háló pedig leggyakrabban professzori levelezésekből és a peregrináló diákok közvetítésével alakulhatott ki [22]. Ez egyben azt is jelenti, hogy a peregrináció érdemben járult hozzá évszázadokon keresztül a társadalmi csúcselit kialakulásához, amelyben az akadémiai és egyetemi hierarchia legmagasabb fokán álló kutatók is képviseltetik magukat [23]. Ezt a folyamatot napjainkban a felsőoktatás hálózatosodásaként vizsgálják egyre több helyen és módon - kijelenthető, hogy már a középkori vagy a felvilágosodás korának felsőoktatása is értelmezhető hálózatként, hiszen megfelel mindazoknak a kritériumoknak, amelyeket például Bertalan Péter is említ, ugyanis több egyént és szervezetet fognak össze tartós módon, az alkotó személyek és szervek között kölcsönösen és - legalábbis a kor technikai és hírközlési körülményeihez mérten - gyakran történnek interakciók és ezek alapján hosszú távra alakulnak ki olyan együttműködések, amelyek célja kölcsönös előrejutás, kölcsönösen nyertes szituációk megteremtése [24].

A magyar felsőoktatás nemzetköziesedési lehetőségeit erősen befolyásolta a tény, hogy eleve Magyarország is egy többnemzetiségú államként létezett a 18-19. század folyamán, ráadásul a Mária Terézia királynő nevéhez fűződő 1777-es Ratio Educationis rendezte a felsőoktatás rendszerét is. Ennek keretében Magyarországon még a 19. század elején is a latin volt a felsőoktatás hivatalos nyelve, amely utolsó európai államként egészen 1844-ig kitartott a latin nyelven zajló oktatás mellett. Később a magyar nyelvű oktatás egyébként számos konfliktust generált a kisebbségek és a magyarság között [25].

Az 1867-ben létrejött Osztrák-Magyar Monarchián belül Magyarország éves költségvetésének egyre nagyobb arányát költötte oktatásra - 1914-ben 9,4\%-nyi ráfordítás jutott oktatási és kulturális kiadásokra [26]. Ebben az időszakban a felsőoktatás is komoly fejlődésnek indulhatott. Ebben az időszakban számos új oktatási épület létesült és sor került olyan, a magyar felsőoktatás egészét máig meghatározó intézmények megalapítására is, mint a Műegyetem, a Zeneakadémia, a Képzőművészeti Egyetem és a nagy vidéki egyetemek Debrecenben, Pozsonyban és Kolozsvárott- ez utóbbiak később Pécsre és Szegedre költöztetve folytatták működésüket [27] . Erre az időszakra tehető a közgazdasági képzés megindulása is hazánkban (a 20. század elején a Műegyetemen), Wlassics Gyula miniszterségétől kezdve pedig - a jogi kar kivételével - nők is felvételt nyerhettek a felsőoktatási intézményekbe [26]. Wlassics eredeti terveitől eltérően I. Ferenc József 1895-ben még csak a bölcsészeti, orvosi és gyógyszerészeti szakokra engedélyezte a nők felvételét, azonban a történelmi folyamatok, részint a feminista mozgalmak erősödése, részint pedig a világháború miatt egyre több lehetőséghez jutottak a hölgyek, akik 1918 óta, a vallási és közoktatási miniszter 206626/1918 számú rendelete óta korlátozástól mentesen kezdhettek felsőfokú tanulmányokat [28]. A felsőoktatási intézmények forrásainak bővülésével és a felvehető hallgatók körnek szélesebbé válásával a magyar felsőoktatás nemzetköziesedési lehetőségei is kibővültek. Mint az látható, a korszakban eleve igény nyílott a nemzetközi mobilitás megerősítésére.

A dualizmus korában a nemzetközi mobilitás általános körülményei - a technikai forradalomnak, a közlekedési innovációknak köszönhetően - jelentősen megváltoztak. Antal és Baksa tanulmányában a magyarországi gazdaságtudományi képzések fejlődése szempontjából fontos kereskedelmi akadémiai képzést elemezve vizsgálta a Keleti Kereskedelmi Akadémia müködését. A vizsgált intézmény hallgatói különböző intézményi, minisztériumi és további ösztöndíjak támogatásával utaztak külföldre annak 
érdekében, hogy gyakorlati ismeretekre tehessenek szert azzal az országgal kapcsolatban, amelyekben később dolgozni fognak. A tanulmány szerint a hallgatók rövidebb vagy hosszabb idejű mobilitás keretében eljutottak Romániába, balkáni és kis-ázsiai országokba, de olyan célpontokba is, mint Kairó, Toulouse, Buenos Aires, Genova, New York, London vagy Liverpool [29].

Az első világháború lezárultát követő időszak meghatározó oktatáspolitikusa gróf Klebelsberg Kunó volt. Klebelsberg minisztersége alatt számos előrelépés történt a magyar oktatásügy területén, amelyek közül jelen disszertáció szempontjából a legnagyobb jelentőséggel az 1927. évi XIII. törvénycikkel létrehozott külföldi magyar intézetek és a magas múveltség célját szolgáló - külföldi - ösztöndíjak voltak. Mint azt Bognár is összefoglalja cikkében, a külföldi továbbképzés támogatására és a magyar kultúra népszerűsítésére létrehozott intézetek Párizsban, Rómában, Bécsben, Berlinben és Zürichben működtek, lehetővé téve magyar fiataloknak, hogy ezekben a városokban folytassanak tanulmányokat vagy kutatásokat [30]. Klebelsberg maga is írt a Collegium Hungaricumokról: írásában a római intézménynek elsősorban a művészeti képzésben szánt jelentősebb feladatokat, míg a párizsi esetében a francia kormánnyal folytatott előrehaladott állapotú, sikerrel kecsegtető tárgyalássorozatról írott beszámolójával erősíti meg, hogy a Collegium Hungaricumok a fogadó országgal jó együttműködésben végezték tevékenységüket [31].

A második világháborút követően, a Rákosi-diktatúra időszakában a felsőoktatási rendszer is drasztikus átalakuláson ment keresztül. Korábban kifejezetten jellemző volt a nyugatos kapcsolati tőke és a külföldi tanulmányokat folytató hallgatók is egyre nagyobb számban jelentek meg. Ehhez mérten az ország szovjet típusú átalakítása a felsőoktatást sem kerülhette el, ez a körülmény pedig alapjaiban határozta meg a felsőoktatási rendszer egészének működését: az irányítást, a felügyeletet és az autonómiát illetve annak hiányát is [32]. Ebben az időszakban az egész pedagógiai rendszer működésére a legnagyobb hatást a szovjet eljárásrend, oktatáspolitika és maga a Szovjetunió tette. Az oktatásmódszertani és -szervezési kérdésekben is a szovjet minta volt követendő, ezt jól jelképezi, hogy az összes korabeli pedagógiai szaklap elsődlegesen a szovjet oktatástudomány eredményeit igyekezett átvenni és népszerűsíteni, jobb esetben a helyi viszonyokra alkalmazni [33].

Az 1989-es rendszerváltás előtt egyáltalán nem volt tipikus az, hogy az egyetemisták vagy főiskolások külföldön folytassanak tanulmányokat. Elenyésző számban voltak ugyan, akik tanulmányi céllal - legális úton - kérvényezték a külföldre költözés lehetőségét, azonban ez a jelenség távolról sem volt tipikusnak nevezhető. Nagyobb számban akadtak, akik szüleik külszolgálata idején fordultak meg valamely külföldi felsőoktatási intézményben. Emellett meg kell említeni, hogy úgynevezett pártösztöndíjjal érkeztek külföldi hallgatók az országba (évente mintegy 5000 fő), illetve a keleti blokk országaiba hasonló módon magyarok is kijuthattak (évente nagyságrendileg 500 fős keret erejéig) [34].

\section{Összefoglalás}

Az egyetemes tudománytörténet és a felsőoktatás fejlesztése szempontjából a felsőoktatás nemzetközivé válásának jelentős szerepe volt. A tudás áramlása, az új felfedezések földrajzi elterjedése és a nemzetközi kutatási-tudományos együttműködések kialakulásának legegyszerűbb módja évszázadokon keresztül a nemzetközi mobilitás volt - úgy az oktatók, mint a hallgatók részéről. A felsőoktatás által megvalósítani kívánt társadalmi célok alakulásával a felsőoktatás nemzetköziesedését 
eredményező folyamatok is változó hatással jelentek meg. A jelenlegi intenzív nemzetköziesedési folyamat azonban a legkevésbé sem előzmények nélküli, a felsőoktatási intézmények szervezésével kapcsolatos feladatok egy része a középkori egyetemek idejéből már ismert.

Összességében tehát látható, hogy a magyar felsőoktatási rendszer nemzetköziesedése komoly történelmi gyökerekkel és hagyományokkal rendelkezik, ugyanakkor a jelenség kialakulása egyáltalán nem tekinthető fokozatos, szerves fejlődés eredményének. A jelentősebb történelmi események ugyanis kivétel nélkül hatottak erre a folyamatra is.

A történelmi események hatására időnként komoly visszaesések következtek be (lásd például az erőskezű Anjou-uralkodókat követő anarchikus időszak vagy a török hódítás hatásait), míg más esetekben a politikai és történelmi változások lendületet adtak a felsőoktatási rendszer fejlődésének és a nemzetköziesedési folyamatnak is (például a kiegyezés 1867-es megtörténte).

A 20. század történelmi fordulói komolyan visszavetették a felsőoktatás nemzetköziesedésének folyamatát: a trianoni békeszerződéssel összefüggésben a nemzetközi mobilitási lehetőségek beszűkültek, a két világháború idején az egész oktatási rendszer komoly nehézségek mellett tudott működni - ha működött egyáltalán, míg az 1940-es évek végétől az erőszakos szovjetizálás és a kétpólusú világrend akadályozta a nemzetköziesedés fellendülését az egyetemek és a főiskolák esetén.

Napjainkra ez a probléma elhárult, hiszen a felsőoktatási rendszerek átjárhatósága, a nemzetközi mobilitás elterjedése és népszerűvé válása a legfontosabb felsőoktatási trendek részét képezi. A globális migrációs trendeken belül az oktatási célú kivándorlás fontos motivációt jelent még akkor is, ha a népvándorlás elsődleges motivátoraként nem a tanulmányi célokat jelölhetjük meg [35]. Az oktatási célú mobilitás, mint migrációs és a tudás transzferálását elősegítő jelenség, napjaink egyik igen széles körben kutatott témája [36], a folyamat intenzitását pedig - a tudás iránti igények alapján - a képzések tartalma is jelentősen befolyásolja [37], alátámasztva ezzel a multidiszciplináris kutatások elterjedését igazoló kutatásokat, illetve a különböző ágazatok komplex tudás iránti igényét [38]. A tudástranszfer szempontjából is jelentős az a nézetkülönbség, amely az európai és az észak-amerikai felsőoktatási rendszerek nemzetköziesedése között történelmileg is megfigyelhető volt: Európában sokkal hangsúlyosabb motivációs tényezőként jelent meg a nemzetek békevágya [39]. A nemzetközi mobilitás trendjei folyamatosan változnak, ami kihat a transzferált tudás jellegére is a kulturális különbségek mentén [40], amely a diplomások leendő munkáltatóira is hatást gyakorol, hiszen az eltérő hattérrel rendelkező tehetségeket eltérő módon lehet megtartani [41].

\section{Hivatkozások}

[1] De Wit, H. (2017): Internationalisation of higher education: Nine misconceptions. In: Mihut, G., Altbach, P. G., de Wit, H. (szerk.): Understanding higher education internationalization. Insights from Key Global Publications. Sense Publishers, Rotterdam. pp. 9-12.

[2] Altbach, P. G., de Wit, H. (2017): Internationalization and global tension: Lessons from history. In: Mihut, G., Altbach, P. G., de Wit, H. (szerk.): Understanding higher education internationalization. Insights from Key Global Publications. Sense Publishers, Rotterdam. pp. 21-24. 
[3] Babbie, E. (2014): The basics of social research. Sixth edition. Wadsworth Cengage Learning, Belmont.

[4] Dźwigoł, H., Dźwigoł-Baros, M. (2018): Scientific research methodology in management sciences. Financial and Credit Activity: Problems of Theory and Practice, Vol. 25, No. 2. pp. 424-437.

[5] Kothari, C. R. (2004): Research methodology. Methods \& techniques. Second revised edition. New Age International Publishers, New Delhi.

[6] Vámos, T. (2017): Van-e szamárlétra a tudomány mennyországába? Magyar Tudomány, Vol. 178, No. 5. pp. 607-609.

[7] Ivan, S. (2011): The new paradigm of higher education in the knowledge society. Journal Plus Education, Vol. 7, No. 2. pp. 46-59.

[8] Gonon, P. (2004): Travel and Reform: impulses towards internationalisation in the nineteenth-century dicourse on education. In: Phillips, D., Ochs, K. (szerk.): Educational Policy Borrowing: historical perspectives. Symposium Books, Oxford. pp. 125-143.

[9] De Ridder-Symoens, H. (1992): Mobility. In: De Ridder-Symoens, H. (szerk.): A history of the university in Europe: Volume I. Universities in the Middle Ages. Cambridge University Press, Cambridge. pp. 280-305.

[10] Szögi, L.: Külföldi egyetemi modellek és külföldi egyetemi tanulmányok a 18. századtól a 20. század elejéig. Forrás: http://tbeck.beckground.hu/filo/htm/1/107_belso.htm Utolsó letöltés dátuma: 2017. 08. 08.

[11] Réau, B. (2016): Tourism, Educational Travel, and Transnational Capital: From the Grand Tour to the 'Year Abroad' among Sciences Po-Paris Students. In: Koh, A., Kenway, J. (szerk.): Elite Schools. Multiple Geogrpahies of Privilege. Routeledge, New York. pp. 188-202.

[12] Gazda, I. (2013): Magyar tudománytörténet. A reáltudományok területén magyar kutatók által 1945 előtt elért kiemelkedő eredményekből. Történeti összefoglalók, bibliográfiák. Magyar Tudománytörténeti Intézet, Budapest.

[13] Altbach, P. G. (1998): Comparative perspectives in higher education for the twenty-first century. Higher Education Policy, Vol. 11, No. 4. pp. 347-356.

[14] De Wit, H., Merkx, G. (2012): The history of internationalisation of higher education. In: Deardorff, D., de Wit, H., Heyl, J., Adams, T. (szerk.). The SAGE handbook of international higher education. SAGE, Thousand Oaks. pp. 43-59.

[15] De Wit, H., Hunter, F. (2015): Understanding internationalisation of higher education in the European context. In: Internationalisation of the higher education. European Parliament, Bruxelles. pp. 41-58.

[16] Zoontjens, P. J. J. (2001): Higher education is Europeans space: Companies in a state context. European Journal for Education Law and Policy. Vol. 5, No. 1-2. pp. 165-168. 
[17] Finlay, J. (2015): Legal Education 1650-1850. In: Anderson, R., Freeman, M., Paterson, L. (szerk.): The Edinburgh Histroy of Education in Scotland. Edinburgh University Press, Edinburgh. pp. 114-132.

[18] Жуковская, T. Н. (2013): PEREGRINATIO ACADEMICA: Подготовка профессорантов Санкт-Петербургского университета в Европе в начале XIX. в. Вестник СанктПетербургского Университета. Vol. 2, No. 3. pp. 30-42.

[19] Bagge, S. (1984): Nordic Students at Foreign Universities Until 1660. Scandinavian Journal of History. Vol. 9, No. 1. pp. 1-29.

[20] Szögi, L. (2017): A magyar protestáns peregrináció a 16-18. században. Gerundium, Vol. 8, No. 1. pp. 71-78.

[21] Kovács, S. (2009): A magyar unitárius peregrinatio academica vázlatos története 1848 után. Keresztény Magvető, Vol. 115, No. 4. pp. 561-587.

[22] Hegyi, Á (2015): Magyarországi orvostanhallgatók Bázelben készült disszertációinak szerepe a hazai orvostársadalom ismereteinek alakításában a 18. században. Gerundium, Vol. 6, No. 3-4. pp. 29-40.

[23] Nagy, P. T. (2013): Elitszociológia és neveléstörténet-írás. Neveléstudomány, Vol. 2013, No. 3. pp. 40-59.

[24] Bertalan, P. (2015): Hálózatok az oktatásban. Acta Scientiarium Socialium, 43. pp. 9-21.

[25] Szögi, L. (2017): On University Histography in Hungary: An Overview of the Past 25 Years. CIAN - Revista de Historia de las Universidades, Vol. 20, No. 1. pp. 221-250.

[26] Mann, M. (2003): A modern polgári oktatási rendszer kiépülése és ellentmondásai. Iskolakultúra, Vol. 13, No. 6-7. pp. 59-62.

[27] 1921. évi XXV. törvénycikk 1.§.

[28] Ladányi, A. (1996): Két évforduló. A nôk felsőfokú tanulmányainak száz éve. Educatio, Vol. 1996, No. 3. pp. 375-389.

[29] Antal, Zs., Baksa, M. (2015): A magyar közgazdasági és kereskedelmi oktatás kezdetei. In: Antal, Zs., Baksa, M., Noszkay, E. (szerk.): A 20. századi magyar vezetôképzés, vezetés- és szervezéstudomány története. Budapesti Corvinus Egyetem, Budapest. pp. 127-136.

[30] Bognár, Gy. (2016): Tehetségfelfogás és tehetséggondozási törekvések Magyarországon az 1920-as években. Opus et Educatio, Vol. 3, No. 5. pp. 513-526.

[31] Klebelsberg, K. (1929): A vallás- és közoktatásügyi miniszteri tárca 1929/30. évi elóirányzatának általános indoklása. In: Klebelsberg, K.: Küzdelmek könyve. Athenaeum, Budapest. p. 299.

[32] Szabóné Mojzes, A. (2012): Expanziós folyamatok a felsőoktatásban. Doktori értekezés. Pécsi Tudományegyetem „Oktatás és Társadalom” Neveléstudományi Doktori Iskola, Pécs.

[33] Géczi, J. (2006): A szovjet pedagógiai minta. Iskolakultúra, Vol. 16, No. 9. pp. 24-38. 
[34] Langerné Rédei, M. (2009): A tanulmányi célú mozgás. Akadémiai doktori értekezés. Reg-Info Kft, Budapest.

[35] Dajnoki K. - Máté D. - Fenyves V. - Kun A. I. (2017): Deconstructing attitudes towards immigrant workers among Hungarian employees and higher education students. Sustainability, 2017, 9, 1639.

[36] Cseh Papp I. - Bilan, S. - Dajnoki K. (2018): Globalization of the labour market - Circular migration in Hungary. Journal of International Studies, Vol. 12, No. 2. pp. 182-200.

[37] Csapó Zs. - Nábrádi A. - Kovács K. - Csapóné Riskó T. (2017): MBA education at the University of Debrecen and its further development towards double degree programmes. Applied Studies in Agribusiness and Commerce - APSTRACT, Vol. 11, No. 1-2. pp. 167-170.

[38] Popp J. - Balogh P. - Oláh J. - Kot, S. - Harangi-Rákos M. - Lengyel P. (2018): Social network analysis of scientific articles published by Food Policy. Sustainability, 2018, 10(3), 577. pp. $1-20$.

[39] Fenyves V. - Bács Z. - Kovács B. - Tarnóczi T. - Nemeslaki A. - Böcskei E. (2019): Analysis of factors influencing foreign studies-Strategic decisions-Results of a Hungarian survey. Journal of Entrepreneurship Education, Vol. 22, No. 5. pp. 1-21.

[40] Böcskei E. - Bács Z. - Kovács B. - Tarnóczi T. - Fenyves V. (2019): A nemzetközi diplomamobilitás stratégiai irányvonalai - a Magyarországon tanulmányokat folytató külföldi hallgatók motiváció, a külföldi tanulmányokat befolyásoló tényezők vizsgálata. Competitio, Vol. 18, No. 1-2. pp. 3-38.

[41] Dajnoki K. - Héder M. (2017): „Új szelek fújnak” - a HR válasza a globalizáció és a változás kihívásaira. Hadtudomány - A Magyar Hadtudományi Társaság Folyóirata 27, E-szám. pp. 84-93. 